\title{
Implementasi Kebijakan Promosi Potensi Ekonomi Daerah DPMPTSP Kabupaten Sukoharjo
}

\author{
Tithan Wulung Suryata \\ STIA-ASMI Solo \\ mayasariana92@email.com
}

\begin{abstract}
Abstrak Kabupaten Sukoharjo memiliki potensi ekonomi daerah yang dapat ditawarkan kepada investor sehingga akan menarik investasi daerah dan mendorong pertumbuhan ekonomi. Penelitian ini bertujuan untuk mendeskripsikan implementasi kebijakan promosi potensi ekonomi di Daerah Dinas Penanaman Modal Dan Pelayanan Terpadu Satu Pintu (DPMPTSP), Kabupaten Sukoharjo. Metode yang digunakan kualitatif fenomenologi, memberikan perhatian utama pada bagaimana kebijakan dibuat, dan bagaimana pengaturan implementasinya. Data primer diperoleh dari wawancara dengan informan dan data sekunder dari dokumen yang berkaitan dengan implementasi kebijakan promosi potensi ekonomi di DPMPTSP, Kabupaten Sukoharjo. Analisis data dilakukan dengan reduksi data, tampilan data, dan verifikasi. Dari hasil analisa diperoleh kesimpulan berupa kebijakan implementasi promosi potensi ekonomi di DPMPTSP, Kabupaten Sukoharjo dilakukan secara terus menerus sebagai bentuk pengenalan potensi ekonomi daerah. Faktor komunikasi, sumber daya, disposisi, struktur birokrasi dan dukungan ekonomi, sosial, budaya lingkungan dalam implementasi, Beberapa faktor pendukung ini sekaligus merupakan faktor penghambat karena masih kurang optimal, antara lain: Komunikasi, Sumber Daya, dan Disposisi, Ada beberapa kendala dalam implementasi kebijakan promosi tetapi jumlah investasi ke Kabupaten Sukoharjo melebihi target yang ditetapkan.
\end{abstract} $\begin{array}{ll}\text { Kata Kunci Implementasi Kebijakan, Promosi Potensi Ekonomi Daerah, } & \\ \text { DPMPTSP }\end{array}$

\section{PENDAHULUAN}

Garis-garis Besar Haluan Negara (GBHN) dan Rencana Pembangunan Lima Tahun (REPELITA) sebagai instrumen utama dari penyelenggaraan pemerintahan Orde Baru sarat dengan konsep dan rencana pembangunan(Habibi, 2015)(Mahdi, 2016). Atas dasar tersebut pola hubungan pusat daerah dari paternalistik dan sentralistik diubah menjadi hubungan bersifat kemitraan dan desentralistik.(Christia \& Ispriyarso, 2019)(Fauzi, 2019)(Habibi, 2015) Dilihat dari kepentingan pemerintah pusat ada empat tujuan utama kebijakan desentralisasi dan otonomi antara lain : pendidikan politik, pelatihan kepemimpinan, menciptakan stabilitas politik, dan mewujudkan demokratisasi sistem pemerintahan di daerah(Joniarta, Sucitawathi P, Soares, \& Suderana, 2019)(Kosasih, 2019). 
Kemudian jika dilihat dari sisi kepentingan pemerintah daerah antara lain, mewujudkan political equality, menciptakan local accountability, dan mewujudkan local responsiveness.(Nur \& Susanto, 2019)(Nuradhawati, 2019)(Rahman \& Muhafidin, 2019)(Simanjuntak, 2015). Otonomi daerah memerlukan kombinasi yang efektif antara visi yang jelas serta kepemimpinan yang kuat dari pemerintah pusat, dengan keleluasaan berprakarsa dan berkreasi dari pemerintah daerah. Visi otonomi daerah itu dapat dirumuskan dalam tiga ruang lingkup interaksinya yang utama : politik, ekonomi, sosial dan budaya(Mahdi, 2016). Beberapa fenomena kultural-politis, yang dapat menjadi potensi kendala pelaksanaan otonomi daerah antara lain partisipasi masyarakat rendah, sikap dan mentalitas penyelenggara Pemerintah Daerah, uniformitas, ketergantungan, kecenderungan dominasi kekuasaan oleh pusat dan propinsi, sumber daya daerah dan sistem data daerah.(Christia \& Ispriyarso, 2019)(A Anisah, S Soedwiwahjono, 2018) Kabupaten Sukoharjo merupakan Kabupaten yang mempunyai banyak prestasi.(BPKM, 2017) Beberapa prestasi tersebut menunjukkan kemampuan Kabupaten Sukoharjo dalam pengelolaan wilayahnya. Namun hal tersebut belum signifikan dengan jumlah pendapatan asli daerahnya. Kabupaten Sukoharjo mempunyai industri pengolahan yang dapat dikategorikan menjadi industri besar, menengah dan kecil yang masing-masing terdiri dari ; industri tektil dan farmasi, industri kerajinan (jamu, mebel dan furniture, genteng, batik tulis, gitar, rotan, gamelan), industri aneka (kaca grafir dan ukit kaca, tatah sungging, rasikan dan jenang dodol, thengkleng), industri pertanian(Maryani, 2013) (Dona \& Dona, 2019)(A Anisah, S Soedwiwahjono, 2018)(BPKM, 2017)(Daerah, 2017) Keberhasilan pemasaran daerah dapat diukur dari peningkatan perekonomian daerah yang ditandai dengan pertumbuhan jumlah dan nilai investasi.(Bappenas RI, 2015)(Buana, Aria Langlang, Saragih, Herlina Juni Risma \& Aritonang, 2018)(Pembangunan, 2019) (Ni Luh Emi Damayanti, 2014) .

Kemampuan daerah mengimplemetasikan kebijakan secara konsisten menimbulkan citra yang positif yang akan membuka peluang investasi bagi investor yang potensial. Untuk itu menjadi penting segenap potensi ekonomi daerah perlu dipromosikan. Promosi merupakan salah satu kunci memperkenalkan potensi daerah beserta atributnya kepada wisatawan, pedagang maupun investor yang akan mendukung peningkatan laju pertumbuhan ekonomi daerah.(BPKM, 2017)(Henry Loewendahl (CEO) dan Scott Bryan (Mitra Senior) \& WAVTEQ, 2019)(Ni Luh Emi Damayanti, 2014)

Merujuk pada pendapat tersebut maka segala potensi Kabupaten Sukoharjo harus disosialisasikan melalui sistem promosi potensi ekonomi daerah yang memadai. Pemerintah daerah berusaha menunjukkan diri dan terbuka menawarkan segala bentuk kemudahan dan fasilitasnya dengan implementasi kebijakan promosi potensi ekonomi daerah pada Dinas Penanaman Modal dan Pelayanan Terpadu Satu Pintu di Kabupaten Sukoharjo.

\section{LANDASAN TEORI}

\section{A. 1. Kebijakan Publik}

Kebijakan public merupakan segala sesuatu yang dikerjakan pemerintah, mengapa mereka melakukan, dan hasil yang membuat sebuah kehidupan bersama tampil berbeda(Thomas R. Dye, 2008) Penyelenggaraan perekonomian ditentukan dalam UUD 1945 Pasal 33 UUD 1945. 


\section{Implementasi Kebijakan}

Aspek yang terpenting dalam suatu kebijakan adalah implementasi dari kebijakan.(Tahir, 2011)(Maghfirullah, 2018). Pengembangan partisipasi masyarakat dalam implementasi kebijakan publik di era otonomi daerah diperlukan prasyarat inisiatif pemerintah daerah, good societal governance, serta membangun kepedulian dan pelatihan masyarakat.

\section{Potensi Ekonomi Daerah}

Potensi ekonomi daerah sebagai kemampuan ekonomi yang ada di daerah yang mungkin dan layak dikembangkan sehingga akan terus berkembang menjadi sumber penghidupan rakyat setempat bahkan dapat mendorong perekonomian daerah secara keseluruhan untuk berkembang dengan sendirinya dan berkesinambungan.(Suparmoko, 2012)(Adisasmita, 2013) Sehubungan dengan potensi ekonomi yang dimiliki suatu daerah maka Pemerintah Daerah (Pemda) dengan demikian harus lebih memahami karakteristik pasar.

\section{Promosi Potensi Ekonomi Daerah}

Promosi adalah komunikasi yang persuasif, mengajak, mendesak, membujuk, meyakinkan(Algifari, 2013)(Barokah, 2014). Proses promosi menekankan kepada bagaimana cara mengkomunikasikan suatu produk kepada pelanggan/customer untuk membentuk citra positif dimata para customer. Obyek target promosi daerah adalah TTI (Tourist, Traders, Investor) dan TDO (Talent, Developer, Organizer)

\section{Pendapatan Asli Daerah}

Berdasarkan Undang-Undang Nomor 33 Tahun 2004 tentang Perimbangan Keuangan Antara Pusat dan Daerah Pasal 1 angka 18 bahwa "Pendapatan asli daerah, selanjutnya disebut PAD adalah pendapatan yang diperoleh daerah yang dipungut berdasarkan peraturan daerah sesuai dengan peraturan perundang-undangan". Pasal 6 menyebutkan bahwa PAD bersumber dari pajak daerah, retribusi daerah, hasil pengelolaan kekayaan Daerah yang dipisahkan, dan lain-lain PAD yang sah.

Kerangka penelitian ditunjukkan pada Gambar 1.,

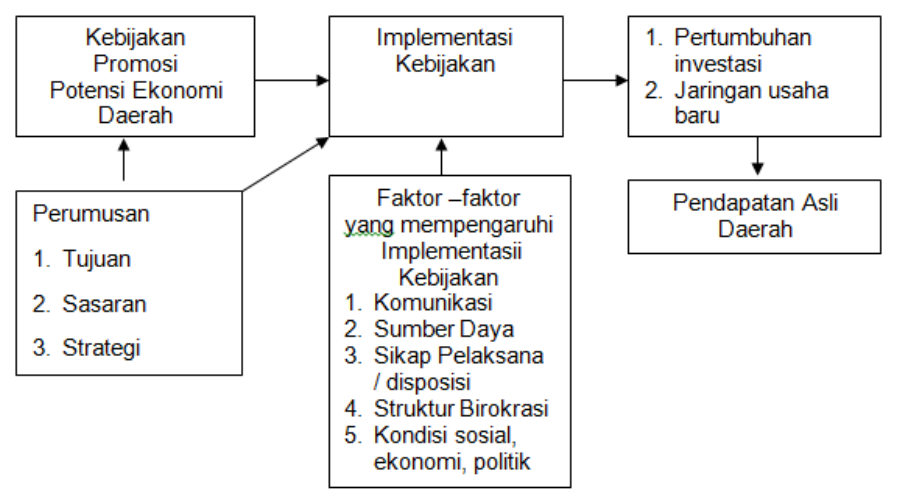

\section{METODOLOGI PENELITIAN}

Gambar 1. Kerangka Konsep Penelitian

Penelitian ini menggunakan metode penelitian kualitatif sesuai dengan paradigma intrepretatif dengan pendekatan fenomenologi yaitu untuk mengerti sepenuhnya bagaimana kehidupan sosial tersebut berlangsung harus memahami dari sudut pandang pelaku itu sendiri (Ibrahim, 2015). 
Lokasi Penelitian dilakukan di Dinas Penanaman Modal dan Pelayanan Terpadu Satu Pintu Kabupaten Sukoharjo (DPMPTSP). DPMPTSP merupakan Dinas daerah/lembaga teknis yang menyelenggarakan urusan Pemerintahan bidang penanaman modal dan perizinan terpadu satu pintu.

Jenis dan sumber data dari responden langsung dan portal resmi Kabupaten Sukoharjo (sukoharjo.go.id), website Dinas Penanaman Modal dan Pelayanan Terpadu Satu Pintu (DPMPTSP), buku Buku Potensi dan Peluang Investasi Kabupaten Sukoharjo, dan sejenisnya.

\section{Teknik Pengumpulan Data}

Teknik pengumpulan data dilakukan dengan wawancara (interview), pengamatan atau observasi, dan dokumen.

\section{Pemilihan Informan}

Sebagai informan dalampenelitian ini antara lain,

(1) Bp.Teguh Pramono,SH.,MH selaku Sekretaris Dinas PMPTSP.

(2) Ibu Dra.Sri Hartati selaku Kabid Penanaman Modal.

(3) Ibu Suryani,S.Sos selaku Kasi Promosi dan Kerjasama.

(4) Ibu Ariani Nurmaini,SE.,MSi, selaku Kasi Pengawasan dan Pengendalian

\section{Instrumen Penelitian}

Dalam penelitian kualitatif, peneliti merupakan key instrument. Peneliti melakukan perencanaan, pengumpulan data dan analisis serta kesimpulan dibantu dengan naskah wawancara dan dokumen(Ibrahim, 2015).

\section{Teknik Analisa Data}

Teknik analisis data yang digunakan dalam penelitian kebijakan ini adalah analisis kualitatif. (Miles, 1992)(Moleong, 2007) mengemukakan bahwa analisis data kualitatif terdiri dari tiga langkah yaitu reduksi data, penyajian data, dan penarikan kesimpulan/verifikasi.

\section{HASIL PENELITIAN}

1. Implementasi Kebijakan Promosi Potensi Ekonomi Daerah pada Dinas Penanaman Modal dan Pelayanan Terpadu Satu Pintu di Kabupaten Sukoharjo

Hasil penelitian menunjukkan bahwa pengenalan dan penawaran produk potensi ekonomi daerah telah dilakukan oleh Bidang Penanaman Modal sub bidang promosi dan kerjasama. Kegiatan promosi dilakukan melalui pameran, forum bisnis dan berbagai media promo. Hal ini sebagai upaya mempertemukan pengusaha lokal dengan pengusaha daerah lain sehingga ada peluang usaha yang dapat dipertukarkan keduabelah pihak. Dinas PM dan PTSP Kabupaten Sukoharjo aktif berpartisipasi dalam beberapa pameran baik lingkup lokal, regional maupun nasional, seperti ditunjukkan pada Tabel 1.

TABEL 1 UJI VALIDITAS UNTUK VARIABEL KUALITAS PELAYANAN

\begin{tabular}{|c|l|l|}
\hline No & \multicolumn{1}{|c|}{ Kegiatan } & Jenis Produk \\
\hline 1 & $\begin{array}{l}\text { International Indonesia Furniture } \\
\text { Expo }(\text { IFEX) }\end{array}$ & $\begin{array}{l}\text { Klaster rotan Trangsan dan mebel } \\
\text { Bulakan }\end{array}$ \\
\hline
\end{tabular}




\begin{tabular}{|c|l|l|}
2 & $\begin{array}{l}\text { APKASI International Trade And } \\
\text { Investment Summit }\end{array}$ & $\begin{array}{l}\text { Batik Kedunggudel, batik Adi Busana } \\
\text { Mojolaban dan sampel produk unggulan } \\
\text { Sukoharjo }\end{array}$ \\
\hline 3 & Gelar potensi daerah Sukoharjo & $\begin{array}{l}\text { Batik Kedunggudel dan sampel produk } \\
\text { unggulan Sukoharjo }\end{array}$ \\
\hline 4 & $\begin{array}{l}\text { CJIBF (Central Java Investment } \\
\text { Business Forum) }\end{array}$ & $\begin{array}{l}\text { Batik Kedunggudel, batik Adi Busana } \\
\text { Mojolaban dan sampel produk unggulan } \\
\text { Sukoharjo }\end{array}$ \\
\hline 5 & $\begin{array}{l}\text { Pameran Investasi dan Pelayanan } \\
\text { Publik (INAVEST) }\end{array}$ & $\begin{array}{l}\text { Omah Batik Owen`s Joe, Neo Algael } \\
\text { Herbal dan sampel produk unggulan } \\
\text { Sukoharjo }\end{array}$ \\
\hline
\end{tabular}

Forum bisnis rutin difasilitasi oleh Badan Penanaman Modal Propinsi Jawa Tengah. Forum bisnis tersebut Central Java Investment Business Forum (CJIBF) yang dikemas bersamaan dengan pameran.

Buku dibuat dengan kualitas kertas berwarna elegan dan eklusif, disertai gambar yang menarik. Buku profil berisi antara kain :a) Data posisi geografis Kabupaten Sukoharjo b) Peta potensi, c) Pemerintahan, d) Fasilitas pendukung, e) Gedung pusat potensi daerah, f) Industri unggulan (jamu, jamur, pertanian organik, gamelan), g) UMKM (batik, mebel, rotan), h) Tatah sungging, i) Zona industri dan tenaga kerja, j) Sektor perdagangan, k) Perhotelan, 1) Pusat perbelanjaan, m) Kesehatan, n) Pendidikan.

Video profil potensi dan peluang investasi sebagai pendukung buku profil, digunakan untuk bahan presentasi yang menarik. Format audio visual diharapkan lebih dapat diingat oleh penontonnya karena semua indra tubuh berperan menikmatinya. Pemberitaan dilakukan oleh penyelenggara kegiatan ke media baik cetak maupun elektronik.

Website

\section{Faktor-Faktor yang Mempengaruhi Implementasi Kebijakan Promosi Potensi Ekonomi Daerah pada Dinas Penanaman Modal dan Pelayanan Terpadu Satu Pintu di Kabupaten Sukoharjo}

Kebijakan promosi potensi ekonomi daerah adalah suatu kebutuhan pada tiap daaerah khususnya Kabupaten Sukoharjo. Promosi daerah tidak dilakukan sekali atau cukup dua kali, namun adalah suatu proses berkelanjutan. Implementasi kebijakan tersebut dipengaruhi oleh faktor - faktor antara lain, a) komunikasi, yaitu komunikasi intern dan extern, b) sumber daya, antara lain sumber daya manusia, sumber daya materi, sumber daya metoda, sikap pelaksana/disposisi, struktur birokrasi, kondisi social, ekonomi, politik.

\section{Dampak Implementasi Kebijakan Promosi Potensi Ekonomi Daerah}

a) Pertumbuhan investasi dapat ditunjukkan pada Tabel 2, Gambar 2

TABEL 2 PERKEMBANGAN PERTUMBUHAN INVESTASI DENGAN FASILITAS DAN TANPA FASILITAS

\begin{tabular}{|l|l|c|}
\hline \multirow{2}{*}{ Tahun } & \multicolumn{2}{|c|}{ Investasi } \\
\cline { 2 - 3 } & Fasilitas & Non Fasilitas (Rp) \\
\hline
\end{tabular}




\begin{tabular}{|c|c|r|r|}
\hline & PMA (\$) & \multicolumn{1}{|c|}{ PMDN (Rp) } & \\
\hline Tahun ke-1 & $\$ 3.615 .426$ & Rp762.546.500 & Rp377.508.154.572 \\
\hline Tahun ke-2 & $\$ 37.654 .200$ & Rp777.860.500.000 & Rp4.510.277.190.759 \\
\hline
\end{tabular}

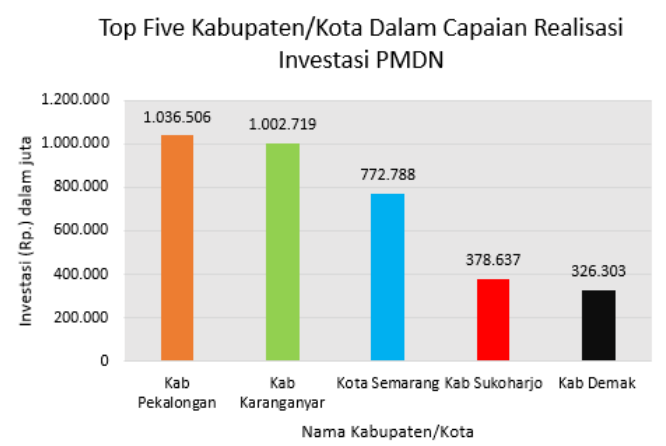

Top Five Kabupaten/Kota Dalam Capaian Realisasi Investasi PMA

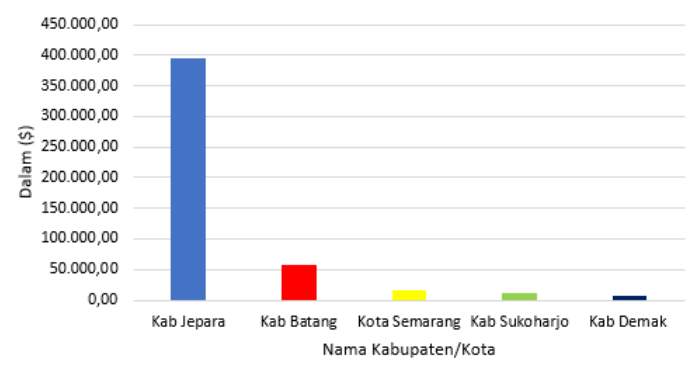

Gambar 2 Capaian realisasi investasi PMDN dan PMA

b) Munculnya Jaringan usaha Baru

Dari pertemuan bisnis yang difasilitasi oleh DPMPTSP beberapa UMKM berhasil mendapatkan mitra kerja dari daerah lain. Ada interaksi usaha baru yang dibutuhkan untuk memenuhi pasar baru tersebut.

\section{KESIMPULAN}

Investasi adalah motor penggerak bagi pertumbuhan ekonomi, pada intinya berupa pemberdayaan daerah. Dimana daerah harus mampu mengatur, mengurus, dan mengelola kepentingan serta aspirasi masyarakat di wilayahnya. Kebijakan promosi potensi daerah merupakan upaya mengenalkan produk daerah sehingga dikenal luas dan dapat direspon pasar. Berdasarkan hasil penelitian dan pembahasan implementasi kebijakan promosi potensi ekonomi daerah pada Dinas Penanaman Modal dan Pelayanan Terpadu Satu Pintu di Kabupaten Sukoharjo dilakukan secara kontinu dan terus menerus sebagai bentuk pengenalan potensi daerah. Faktor komunikasi, sumber daya, disposisi, struktur birokrasi dan lingkungan ekonomi, sosial, budaya mendukung dalam implementasiannya. Ada beberapa faktor pendukung sekaligus juga menjadi faktor penghambat karena masih ada yang kurang optimal, antara lain masih ada hambatan komunikasi yaitu media promosi kurang konsisten, terlihat dari informasi yang ditampilkan pada laman website masih kosong dan atau kurang update. DPMPTSP beberapa layanan publiknya cenderung didorong kearah online, sehingga hal ini kurang mendukung pencitraannya. Metode pengemasan promosi terbatas pada menginformasikan dan menawarkan jenis potensi daerah Kabupaten Sukoharjo, masih pada apa yang dipunyai daerah untuk dipilih oleh pasar. Materi promosi khususnya UMKM unggulan belum menunjukkan pembeda dengan produk potensi daerah lain yang sama. Penyimpanan data hasil kegiatan promosi yang sudah dilakukan secara online melalui website belum menjadi referensi. Data tersebut dapat digunakan sebagai laporan sekaligus bahan referensi evaluasi kegiatan selanjutnya dan juga informasi ke publik. Penyimpanan data/laporan kegiatan secara manual akan membutuhkan waktu lama jika sewaktu-waktu dibutuhkan. Hal ini dikarenakan keterbatasan kemampuan penguasaan teknologi yang dapat membantu sistem penyimpanan data dan kurangnya motivasi untuk dapat menguasainya. Sementara 
untuk update data dalam website belum ada komitmen tinggi untuk menjaga keterbaruan data. Dampak implementasi kebijakan promosi potensi ekonomi daerah pada Dinas Penanaman Modal dan Pelayanan Perizinan Terpadu Satu Pintu di Kabupaten Sukoharjo, walaupun ada beberapa hambatan dalam implementasinya namun jumlah investasi ke Kabupaten Sukoharjo ada peningkatan yang tinggi melebihi target yang telah ditetapkan.

\section{UCAPAN TERIMA KASIH}

Ucapan terima kasih kepada segenap pemangku jabatan pada Dinas terkait khususnya Dinas DPMPTSP Kabupaten Sukoharjo. Bp.Teguh Pramono,SH.,MH selaku Sekretaris Dinas PMPTSP, Ibu Dra.Sri Hartati selaku Kabid Penanaman Modal, Ibu Suryani,S.Sos selaku Kasi Promosi dan Kerjasama, Ibu Ariani Nurmaini,SE.,MSi, selaku Kasi Pengawasan dan Pengendalian.

\section{DAFTAR PUSTAKA}

A Anisah, S Soedwiwahjono, N. M. (2018). Analisis Perkembangan Wilayah Kecamatan Kartasura Sebagai Kawasan Strategis Cepat Tumbuh. 20, 486-499.

Adisasmita, R. (2013). Teori-Teori Pembangunan Ekonomi Pertumbuhan Ekonomi Dan Pertumbuhan Wilayah. Yogyakarta: Graha Ilmu.

Algifari. (2013). Ekonomi Mikro Teori dan Kasus. Yogyakarta: Bagian Penerbitan Sekolah Tinggi Ekonomi YKPN.

Bappenas RI. (2015). Rencana Pembangunan Jangka Menengah Nasional 2015-2019. Rencana Pembangunan Jangka Menengah Nasional 2015-2019, 313. https://doi.org/10.1017/CBO9781107415324.004

Barokah, H. (2014). Indeks Pembangunan Desa 2014. Jakarta: Kementerian PPN/Bappenas.

BPKM. (2017). Penyusunan Peta Potensi Dan Peluang Investasi Daerah Tahun 2017. In Direktorat Pengembangan Potensi Daerah Badan Koordinasi Penanaman Modal (Vol. 53, pp. 1689-1699). https://doi.org/10.1017/CBO9781107415324.004

Buana, Aria Langlang, Saragih, Herlina Juni Risma \& Aritonang, S. (2018). Pengaruh Pengeluaran Pemerintah, Investasi Pemerintah, Investasi Swasta, dan Tenaga Kerja terhadap Pertumbuhan Ekonomi di Pulau Jawa Tahun 2011 - 2015. Jurnal Ekonomi Pertahanan, 4(2), 1-20.

Christia, A. M., \& Ispriyarso, B. (2019). Desentralisasi Fiskal Dan Otonomi Daerah Di Indonesia. Law Reform, 15(1), 149. https://doi.org/10.14710/lr.v15i1.23360

Daerah, O. (2017). Media BPP, Menelisik Sejarah Otonomi Daerah. 
Dan, P., Investasi, P., \& Pariwisata, S. (2012). Potensi dan peluang investasi sektor pariwisata. 19-21.

Dona, F., \& Dona, F. (2019). Kebijakan Pemerintah Kabupaten Sukoharjo dalam Menciptakan Iklim Investasi yang Kondusif. 4.

Erwan Agus Purwanto, P. ., \& Dyath Ratih Sulistiyastuti, M. S. (2012). Implementasi Kebijakan Publik, Konsep dan Aplikasinya di Indonesia. Yogyakarta: Gava Media.

Fauzi, A. (2019). Otonomi Daerah Dalam Kerangka Mewujudkan Penyelenggaraan Pemerintahan Daerah Yang Baik. Spektrum Hukum, 16(1), 119. https://doi.org/10.35973/sh.v16i1.1130

Habibi, M. M. (2015). Analisis Pelaksanaan Desentralisasi Dalam Otonomi Daerah Kota/Kabupaten. Jurnal Pendidikan Pancasila Dan Kewarganegaraan, 3(2), 117-124. https://doi.org/10.1016/0014-4894(54)90048-X

Haris, S. (2007). Desentralisasi Dan Otonomi Daerah : Desentralisasi, Demokratisasi \& Akuntabilitas Pemerintahan Daerah. xvii, 416 p.

Henry Loewendahl (CEO) dan Scott Bryan (Mitra Senior), W., \& WAVTEQ. (2019). Panduan Pengembangan Strategi Promosi Investasi.

Ibrahim. (2015). Metodologi Penelitian Kualitatif. Bandung: Alfabeta.

Joniarta, I. W., Sucitawathi P, I. G. A. A. D., Soares, I., \& Suderana, W. (2019). Implementasi Kebijakan Desentralisasi Administratif di Municipio Dili, Timor-Leste. Politika: Jurnal Ilmu Politik, 10(1), 40. https://doi.org/10.14710/politika.10.1.2019.4056

Kosasih, A. (2019). Reformulasi Perencanaan Pembangunan Nasional Model Garis-Garis Besar Haluan Negara. Jurnal Ilmiah Mizani: Wacana Hukum, Ekonomi Dan Keagamaan, 6(1), 73. https://doi.org/10.29300/mzn.v6i1.2207

Maghfirullah, H. M. (2018). Teori dan Model Implementasi Kebijakan Publik. Ilmu Administrasi Publik Universitas Brawijaya ABSTRAK, (July 2018).

Mahdi, I. (2016). Reformulasi Sistem Perencanaan Pembangunan Nasional Model GBHN Sebagai Pelaksanaan Asas Kedaulatan Rakyat Dalam Rangka Perubahan Ke-V UUD 1945. 1(1), 73-85.

Maryani, N. (2013). Kewenangan Pemerintah Daerah Dalam Penertiban Pertambangan. Jurnal Ilmiah Mahasiswa Surabaya, 2(1), 1-38.

Miles, B. M. dan M. H. (1992). Analisis Data Kualitatif Buku Sumber Tentang Metodemetode Baru. Jakarta: UIP. 
Moleong, L. J. (2007). Metodologi Penelitian Kualitatif. Bandung: Remaja Rosdakarya.

Ni Luh Emi Damayanti, I. N. K. (2014). Pengaruh Kunjungan Wisatawan Asing dan Investasi Terhadap Penyerapan Tenaga Kerja Serta Pertumbuhan Ekonomi. 882-900.

Nur, S., \& Susanto, H. (2019). Desentralisasi Asimetris dalam Konteks Negara Kesatuan. Adminitrative Law \& Governance Journal, 2(4), 631-649.

Nuradhawati, R. (2019). Dinamika Sentralisasi Dan Desentralisasi Di Indonesia. Jurnal Academia Praja, 2(01), 152-170. https://doi.org/10.36859/jap.v2i01.90

Pasaribu, R. B. F. (2010). Investasi dan Penanaman Modal. Investasi Dan Penanaman Modal, (36), 235-278.

Pembangunan, B. (2019). Menghidupkan Kembali GBHN : 85-108.

Rahman, A., \& Muhafidin, D. (2019). Perwujudan Desentralisasi Sebagai Bentuk Akuntabilitas Pemerintah Daerah Kabupaten Cirebon. Transparansi Jurnal Ilmiah Ilmu Administrasi, 2(1), 73-83. https://doi.org/10.31334/trans.v2i1.424

Simanjuntak, K. (2015). Implementasi Kebijakan Desentralisasi Pemerintahan di Indonesia. Jurnal Bina Praja, 07(02), 111-130. https://doi.org/10.21787/jbp.07.2015.111-130

Suparmoko. (2012). Ekonomika Pembangunan Edisi Keenam. Yogyakarta: BPFE.

Tahir, A. (2011). Kebijakan Publik dan Transparansi Penyelenggaraan Pemerintahan Daerah. Bandung: Alfabeta.

Thomas R. Dye. (2008). Understanding Public Policy (12th ed.). Pearson/Prentice Hall, 2008. 